\title{
Comparative perception and knowledge of smallholder farmers on climate change and variation; case of kaka (a) and Bulu (b) tribes in Eastern Meyomessala sub-division of Cameroon
}

\begin{abstract}
Smallholder farmers are confronted with a variety of challenges including climate variation. Agricultural production is aim to improve the livelihood of farmers. Local knowledge can be instrumental in assisting smallholder farmers to adapt and mitigate climate variability. The objective of this study is to evaluate the perception and knowledge of the smallholder farmers on climate variation and their adaptive and mitigation actions. Questionnaires made up of both open and closed questions were completed by the male and female smallholder farmers belonging to Kaka (A) and the Bulu (B) tribes in Eastern Meyomessala Sub-Division of Cameroon. The data of precipitation and temperature variation for 32 years were obtained from the Aerial Base meteorological center from the same agroecological zone for analysis with the farmers' perception. According to the results, $92 \%$ of the respondent of $\mathrm{A}$ and $86 \%$ of the respondent of $\mathrm{B}$ perceived for excessive rainfall and that it occur for a short period. The result also show that $53 \%$ of the respondent of $\mathrm{A}$ and $58 \%$ of respondent in of B practice off-farm activities to compensate for the low income resulting from low harvest due to climate variation. About $32.3 \%$ of the respondent of $\mathrm{A}$ and $25 \%$ of the respondent of $\mathrm{B}$ perceived that the climate variation is caused by man. Although the minority of the respondent $(19.4 \%$ and $5.0 \%)$ of $\mathrm{A}$ and $\mathrm{B}$ respectively perceived for climate variation as causes of anger of the ancestors of the area. There was no significant difference between the $\mathrm{A}$ and $\mathrm{B}$ on the perception and knowledge of smallholder farmers of the causes of climate change and variation. Knowledge of climatic perceptions and adaptations strategies are vital entry points for policy makers to know where to enhance the adaptive capacity of smallholders' during the short rainy season and extended drought periods. The study will contribute to improving on the adaptive and mitigation action of the smallholder farmers on agricultural activities in the area.
\end{abstract}

Keywords: climatic perception, climate change and variability, smallholders farmers
Volume I Issue 3 - 2017

\author{
Darota $\mathrm{N},{ }^{\prime}$ Ngo Ngwe MFS, ${ }^{2}$ Fomekong JL ${ }^{3}$ \\ Institute of Agricultural Research for Development-CEREFEN, \\ Cameroon \\ ${ }^{2}$ Institute of Agricultural Research for Development, National \\ Herbarium of Cameroon, Cameroon \\ ${ }^{3}$ Department of zoology, University of Yaoundé, Cameroon
}

Correspondence: Ngo Ngwe Marie Florence Sandrine, Institute of Agricultural Research for Development, National Herbarium of Cameroon, BP I60 I, Yaoundé, Cameroon, Tel+237 677224363 Email florencengongwe@yahoo.com

Received: June 09, 2017 | Published: October 10, 2017

\section{Introduction}

Agriculture is one of the main sources of livelihoods for vulnerable poor smallholders. ${ }^{1,2}$ Smallholders' continue to face more challenges that impede agricultural productivity. Such challenges include poor infrastructure, poverty, poor policies and poor governance. ${ }^{3}$ Climate change is recently acknowledged as a major challenge to agriculture. ${ }^{3}$ Climate change causes negative impacts on agriculture, destabilizing smallholders' livelihoods. ${ }^{4,5}$ Although, smallholders have been adapting their agriculture to the changing climate since time immemorial. ${ }^{6}$ They are still vulnerable to climate variability. ${ }^{7,8}$ There are fundamental differences between climate change and climate variability. Climate change constitute a shift in meteorological conditions that last for a long period of time usually centuries. Climate variability means deviations in the mean state of climate and inconsistencies (e.g., in occurrence of wind and precipitation extremes), on all temporal and spatial scales beyond those of individual weather events, including short-term fluctuations that happen from year to year. ${ }^{9}$ In this work, both definitions are used. The underline conception is that global climate change causes local scale impact and that it is not possible to treat variability separate from climate change. ${ }^{10}$ Perception are context and location specific due to heterogeneity in factors that influence them such as culture, education, gender, age, resource endowments and institutional factors. ${ }^{11}$ With a projected continued warming of the globe ${ }^{11}$ glaring challenges could be in store for smallholders. ${ }^{12}$ Agricultural improvement can be achieved if smallholders are targeted. ${ }^{13}$ As part of targeting smallholders and solutions for climate variability, local knowledge of farmers becomes very important to enhancing their adaptive capacity. Local knowledge is based on practice and assists farmers to make informed decisions about how to respond to environmental changes and how to improve the amount and quality of their yield. ${ }^{11,14}$ The validity of local knowledge has been shown by scientists through comparison with quantitative climate data analysis. ${ }^{15}$ Various recommendations have been proposed to enhance the adaptive capacities of farmers. Mainstreaming adaptations into national development processes is one such recommendation. ${ }^{11}$ Lack of mainstreaming often leaves the smallholders' adaptive role in agriculture overlooked. ${ }^{16,17}$ Adaptations are of longer-term in nature. ${ }^{15}$ Coping strategies, on the other hand, consist of household practices used as short term measures when confronted with unexpected events such as droughts. ${ }^{15,17}$ Building on the local knowledge would foster adaptive capacity that is acceptable to farmers by promoting and supporting locally developed adaptations. Overall, there is consensus that local knowledge is part 
of the solution to effective adaptation. ${ }^{6,14-16,18,19}$ However, there are limited studies that have elaborated on perceptions of losses of crops and livestock that result from climate variability, yet these perceptions can shape the coping and adaptation strategies of smallholders. ${ }^{11}$ We ask how smallholders perceive climate variability, how and why perceptions are valued. There is no guarantee that having perceptions that climate variation is occurring would prompt effective adaptation responses ${ }^{20}$ The adaptive capacity is influenced by factors such as knowledge about climate, asset, and access to appropriate technology, institutions, policies and perception inter alia. ${ }^{17}$ There are likely to be severe water shortages and serious disturbances in rainfall patterns in many part of African continent. In order to address the issues, the following questions must be answered; what are the perceptions and knowledge of the smallholders on climate variation? Does the variation in climate affect their agricultural activities? How do smallholders farmer response (adapt and mitigate) to climate change and variation? The adaptation theory posits that social, economics, ecological and institutional systems as well as individuals can and do adapt to changing environment. ${ }^{21}$ The aim of this study is to evaluate the perception and knowledge of the local smallholders' farmers on climate change and variation, as well as their mitigation and adaptive capacity.

\section{Materials and methods}

The study is carried out in Meyomessala Sub-Division in Dja and Lobo Division of the southern Region of Cameroon, in the western part of the Dja reserve. The Kaka tribes and the Bulu tribes abbreviated respectively as A and B was targeted among the group identify by Sonké and Couvreur ${ }^{22}$ to evaluate their perception and knowledge on climate change and variation. This study integrated both qualitative and quantitative methods to build on their complementarities for crosschecking information received from the respondents. ${ }^{23}$ Available historical climate data on precipitation and temperature of agroecological zone IV of Cameroon, covering the period from 1979 to 2010 were sourced from the Aerial Base 101 meteorological department for analysis. The Focus group discussions, key informant interviews to understand in detail the perceptions of climate change and variability and responses. These interviews provided data for developing and designing appropriate questionnaire for the structured and semi structured interviews. Questionnaires were used to obtain qualitative data. Discussants of focus group discussion, key informant interviews and questionnaires were purposively selected based on some criteria: (a) knowledge on climatic conditions of the area. For the information on respondent knowledge on climate variation, questions sought causes of the climate variation, perceived seasonal changes, duration of seasons, hotness, and drought in the area. For perception in changes in flood, hotness or coldness, respondent were also asked to state whether the condition has reduced, increase or still the same for the past five years as compared to the past thirty years (b) respondent were asked whether they have been practicing agricultural farming for livelihoods for more than five years(c) Farmers were also asked to state the causes of climate variation, whether the climate variation affects their crops and how they adapt and mitigate in the situation. A discussion guide was used to moderate the focus discussion group. ${ }^{24}$ The Focus discussion groups highlighted the differences between participants. ${ }^{25}$ The Focus group discussants helped to identify appropriate key informants from each tribe based on their family origin and local language. A checklist of questions guided the key informant interviews with a purposeful sample of 24 smallholders with four from each village. Four households participated in a pretest survey conducted in each village in order to identify potential problems associated with the interpretation of the questionnaires. This allowed for restructuring of questions and solving all questionnairerelated problems before the intensive data collection. ${ }^{26}$ Altogether 71 purposively sampled households were administered on the questionnaire, interviewed using structured questionnaires with open and closed questions, ${ }^{27}$ and they had their free options to answer. Questionnaires combined quantitative measurable variables (structured) and qualitative variables (unstructured) $)^{23,28}$ relevant to the study objective.

The data was analyzed based on the points contained in the questionnaires. The available historical climate data of thirty two years were used to compare with the perception of the smallholder farmers. The data analysis was done using SPSS version 20.0 for Windows (Figure 1).

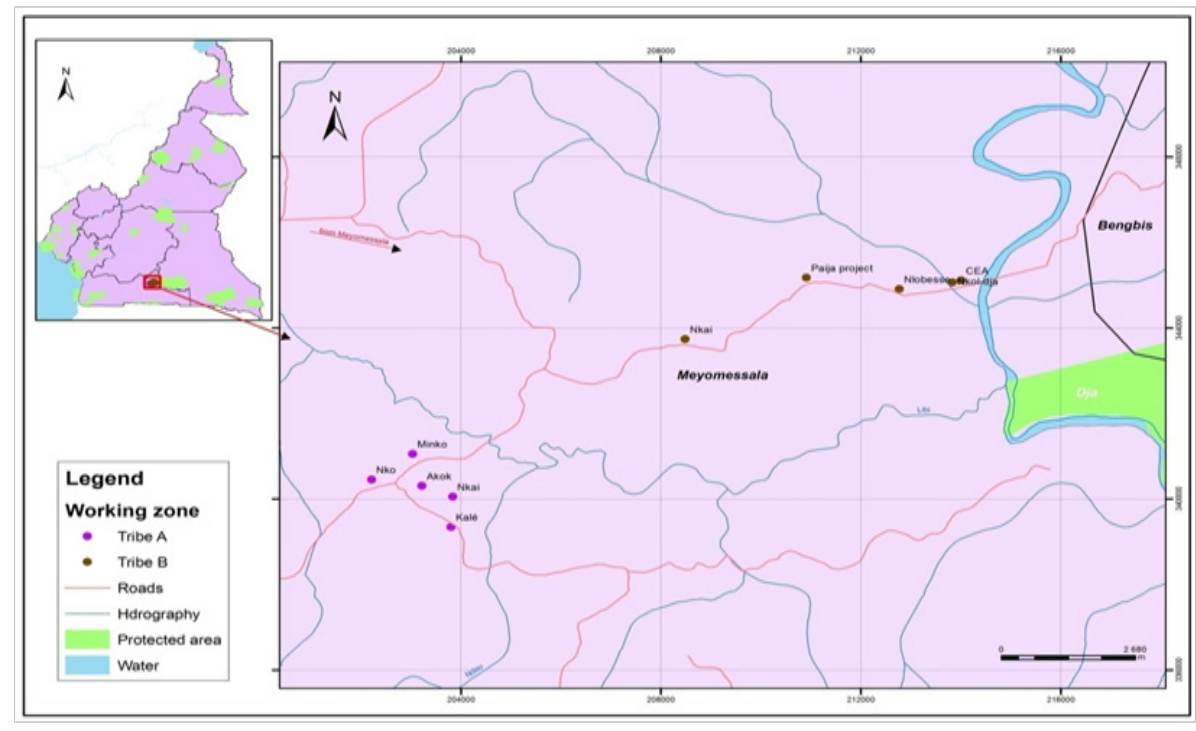

Figure IMap of western entrance of Dja-fauna reserve showing the working zone 


\section{Results}

The males accounted for $67.7 \%$ of the respondent of $\mathrm{A}$ and the female accounted for $37.5 \%$ of B. For both sexes, the average duration period was $16.5 \pm 14.2$ years in both groups. In ethnic group A, 12.9\% of the number of the respondent never attended school as compare to the $2.5 \%$ in ethnic group B. Those who attended primary school was $35.5 \%$ for A against $37.5 \%$ for $\mathrm{B}$, and those with secondary and higher level of education was $51.6 \%$ and $57.5 \%$ respectively as compared to the $0 \%$ and $2.5 \%$ respectively of $\mathrm{A}$ and $\mathrm{B}$.

\section{Perception of changes in onset and offset of seasons}

According to the results, $51.6 \%$ of the respondent of A and $47.5 \%$ of the respondent of B perceived that rainy season comes late and that rainfall occur intensively unlike the past. Also, 25.8\% and $40.0 \%$ respectively of the respondent of $\mathrm{A}$ and $\mathrm{B}$ perceived that dry season comes earlier (Table 1). The Chi-square test gives $\mathrm{P}$-value $=0,367$ showing that there is no statistical differences between the smallholder farmers in both groups in perceiving climate in term of onset and offset of seasons. According to the questionnaires and the focus group discussion, smallholders' farmer perceived that the small dry season that usually occur between July and August and the small rainy season that occurred between March and May does not longer respect the period, and thus making it difficult for farmers to situate the sewing period. They also perceived that, the two main aforementioned seasons fluctuate nowadays as compared to when they were young. A 62 years old farmer of A said "seasonal changes were not contusive and mixed up as we are experiencing nowadays. It gets cold when it is not supposed to and it gets hot when we are not expecting nowadays". They perceived that excessive rainfall destroys their crops through direct raindrops or flood washing away the topsoil and rendering the soil poor. Rainfall is often accompanied by high storms, which blow down their agricultural products.

Table I Percentages of perception of onset and offset of seasons

\section{Perception of the changes in duration of the seasons, temperature, drought and flood}

The result shows that $51.6 \%$ of the respondent of A and $47.5 \%$ of the respondent of B perceived for short duration of the rainy seasons. Respondent were more aware of climate variation related to rainy season than any other seasons. Also $61.3 \%$ of the respondent of A and $75.0 \%$ of the respondent of B perceived for high temperature for the past five years and that it causes their crops to wetter resulting to low agricultural output. The long period of drought as perceived by the smallholder farmers is accompanied by low sunshine and high temperature. Smallholder's farmers perceived that extended drought lower agricultural production and dry up some rivers in the area. A male key informant of 65 years of B said "River Libi has been flooded nowadays and causing us to abandon our cultivated land around the area and some rivers that use to contain water throughout the year has completely dry out". These results show that farmers have local knowledge and perception on the evolution of the local indicator of climate change in their locality and value them.

\section{Perception of causes of climate variation}

About $32.3 \%$ of the respondent of $\mathrm{A}$ and $25 \%$ of the respondent of B perceived that climate variation is caused by man. Although, the minority of the respondent $(19.4 \%$ and $5.0 \%)$ respondent of $\mathrm{A}$ and $\mathrm{B}$ respectively perceived that the anger of the ancestors is at the origin of the cause of the climate change and variation (Table 2). The locals are aware that human action influences on the environment as a man of 52 years from the focus group discussion said "we were told by some $\mathrm{NGO}_{\mathrm{S}}$ to conserve trees in our farms for medication or for shelters but nowadays people are cutting off all trees in their farm". This statement is a clear prove that the smallholder farmers are aware of the importance of role of trees in climate change.

\begin{tabular}{|c|c|c|c|c|c|}
\hline \multicolumn{5}{|c|}{ Onset and offset of seasons } & \multirow{3}{*}{ Tota } \\
\hline & \multicolumn{2}{|l|}{ Rainy seasons } & \multicolumn{2}{|l|}{ Dry seasons } & \\
\hline & No response & $\begin{array}{l}\text { Comes late (short } \\
\text { period) }\end{array}$ & Comes normal & Comese (long period ) & \\
\hline (A)Respondent & 1 & 6 & 8 & 16 & 31 \\
\hline percentages & 3.2 & 19.4 & 25.8 & 51.6 & 100 \\
\hline (B)Respondent & 2 & 3 & 16 & 29 & 40 \\
\hline percentages & 5.0 & 7.5 & 40.0 & 47.5 & 100 \\
\hline
\end{tabular}

Table 2 Percentages of respondent of perception of causes of climate variation and change

\begin{tabular}{lllllll}
\hline \multicolumn{1}{l}{ Causes of climate change } & & & & & \\
\hline & No Response & Ancestors & God & Man & Nature & total \\
\hline (A)Respondent & 6 & 9 & 0 & 10 & 6 & 31 \\
percentages & 19.3 & 29.0 & 0.0 & 32.3 & 19.4 & 100 \\
(B) Respondent & 18 & 2 & 8 & 10 & 2 & 40 \\
percentages & 45.0 & 5.0 & 20.0 & 25.0 & 5.0 & 100 \\
\hline
\end{tabular}

Citation: Darota N, Ngwe NMFS, Fomekong JL. Comparative perception and knowledge of smallholder farmers on climate change and variation; case of kaka (a) and Bulu (b) tribes in Eastern Meyomessala sub-division of Cameroon. Biodiversity Int J. 20 I7; I (3):88-94. DOI: I0.15406/bij.20I 7.0I.000 I4 
Some non-governmental organization had carryout sensitization campaign on environmental conservation in the area to educate the farmers on the important of trees in our environment. From questionnaires the majority of the respondent who perceived man and nature as the cause of climate variation attended the secondary school levels, and those who perceived climate variation cause by ancestors mostly attended the primary school level and those who had never attended school at all. Though the minority cited the ancestral anger as a cause for climate variation, this idea must not be neglected, as more sensitization needs to be done to educate them on the reality. There was no significant difference (Chi-Square $=3.49, \mathrm{Df}=4, \mathrm{P}$-value $=0.001$ ) between the $\mathrm{A}$ and $\mathrm{B}$ on the perception and knowledge of smallholder farmers of the causes of climate change and variation.

\section{Adaptation/copping to climate change and variability by the smallholder farmers}

From the results, $53 \%$ of the respondent of A tribe and $58 \%$ of respondent of B tribe practice off-farm activities to compensate for the low harvest due to climate change and variation. The off-farm activities cited by the smallholders include; small business, preaching, carpentry work, hairdressing, bricklaying, teaching, tapping (Figure 2). The results also show that the farmers of both tribes A and B use complex species of crops to adapt to the changing climate to improve on their yield (Figure 2). These complex plant species cultivated on the piece of land include: Cassava, Cocoa, Egussi, Groundnut, and Maize. During the long drought period, smallholder's farmers perceived they cultivate crops in the swampy lowland area for the availability of water for crops, and during the longer rainy period, they shift cultivation to the dry land (Table 3 )

\section{Mitigation to climate variability by the smallholder farmers}

Smallholder farmers mitigate the climate variation by conserving their forest in various forms such as agroforest, natural forest (Table 4). From the result obtained $38.7 \%$ of tribe $A$ and $55.0 \%$ of the farmers of tribe B practice cocoa-base agroforest system whereby the cocoa plant are integrated with food crop alongside valued tree. One key informant of B during the focus group development said "we were told by some non-governmental organization that we should serve or plant trees in our farms so that it will reduce the ever rising heat in the village". This is evidence that the non-governmental organization had made their sensitization impact on climate mitigation known in the area.

\section{Relationship between smallholder farmers' perception and thirty two years climatic data from the agroecological zone}

The two climatic elements data (temperature and precipitation) collected from the meteorological station of the agroecological zone IV is shown below. The precipitation curve for the zone is not constant. Significant variation is observed in the period 1992 and 2002 where the graph recorded the highest precipitation level. The lowest precipitation measurement is also recorded in the year 1995 (Figure 3). Similarly there are observed variation in temperature for the study area. The highest temperature was recorded in the year 1998 and 2006 with the least temperature recorded in 1992.

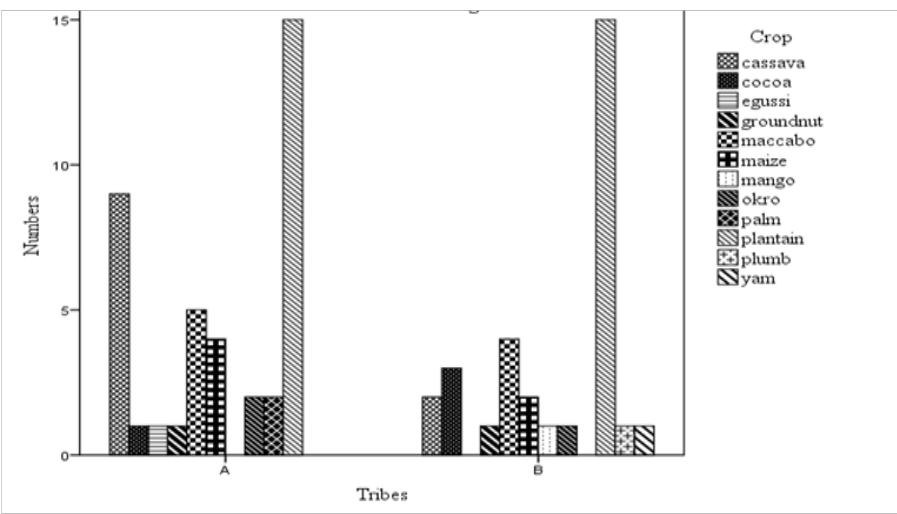

Figure 2 Histogram of smallholder farmer's off-farm activities.

Table 3 Perception of adaptation of smallholder farmers during drought and wet seasons

\begin{tabular}{llllll}
\hline During drought & & & & & \\
& Nothing & Resistant varieties & Swamps and dry land & Watering & Total \\
\hline (A)Respondent & 5 & 4 & 16 & 6 & 31 \\
percentages & 16.1 & 12.9 & 51.6 & 19.4 & 100 \\
(B)Respondent & 1 & 7 & 25 & 7 & 40 \\
percentages & 2.5 & 17.5 & 62.5 & 17.5 & 100 \\
During the wet season & & & & Nothing & Total \\
\hline & Abandon & Resistant varieties & Swamps and dry land & 0 & 31 \\
\hline (A)Respondent & 4 & 20 & 7 & 0 & 100 \\
percentages & 12.9 & 64.5 & 22.6 & 0 & 40 \\
(B)Respondent & 7 & 13 & 20 & 0 & 100 \\
percentages & 17.5 & 32.5 & 50 & & \\
\hline
\end{tabular}

Citation: Darota N, Ngwe NMFS, Fomekong JL. Comparative perception and knowledge of smallholder farmers on climate change and variation; case of kaka (a) and Bulu (b) tribes in Eastern Meyomessala sub-division of Cameroon. Biodiversity Int J. 20I7;I(3):88-94. DOI: I0.I5406/bij.20I7.0I.000 I4 
Table 4 Smallholder's farmer perception of climate mitigation

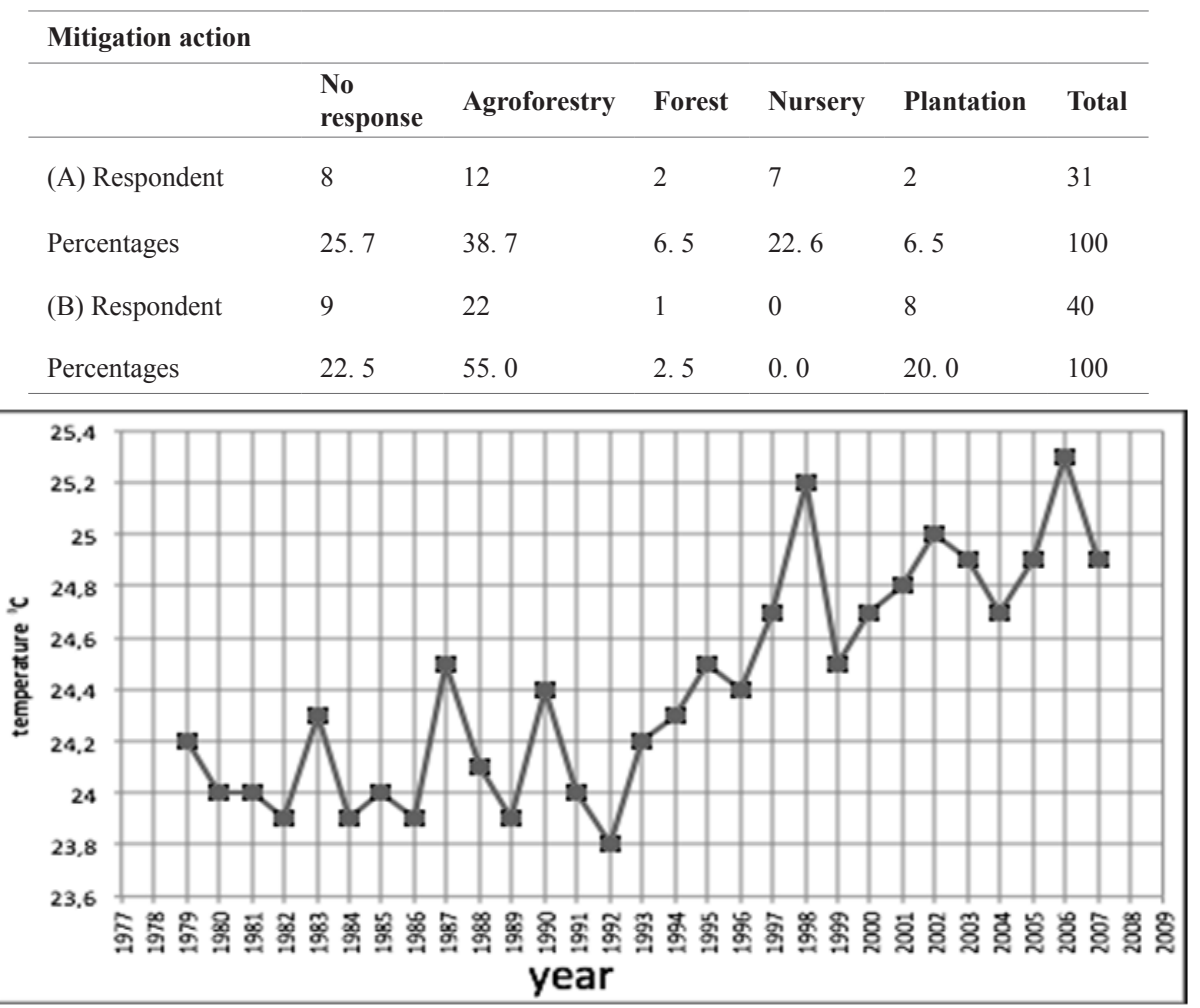

Figure 3 The variations of temperature corroborated with the small farmers perception.

\section{Discussion}

Smallholder farmers in the eastern Meyomessala are aware of the climate variation through their experiences. This is in common with findings from other studies on perception of smallholder farmerss' of climate change and conservation agriculture such as in $\mathrm{Zambia}^{29}$ and in Asia. They accuse the traditional authority for not performing their traditional rites as in the past. Many environmental sensitization groups have made the locals to understand that human action has a lot of influences on the environment that impact on the climate. A lot of sensitization needs to be done in the area to be able to convince those smallholder farmers who perceived the ancestors as cause of climate change so that they can be brought to the lamplight. The year-to-year variability is larger and this can be due to high human activities on the environment. Smallholder farmers perceived that the small dry season known in Bulu as "Engon" that occur between June and August and the big dry season known in Bulu as "Essep" that occur between November and March as well as the big rainy seasons also known in Bulu as Su'uh' that occur between August and November and the small raining season that occur between March and June does not longer respect the period, thus making it difficult for farmers to situate the sewing periods. The result of the 32 years climatic data strengthened this interpretation. The fluctuating precipitation data in the study area are in line with those of the climatic data from eastern China. ${ }^{30}$ Elsewhere, in Ethiopia, farmers reported similar sentiments of reduced rainfalls and changed rainfall patterns. ${ }^{31}$ Also, the increase in temperature from the climatic data corresponds to the perception of temperature increase as perceived by the smallholder farmers. Smallholder farmers in the study area perceived drought in term of water loss for crops or drying up of some of their major rivers they used to irrigate their crops. Some farmers possess agricultural land both on the marshy areas and upland areas. During the long drought period according to the smallholder farmer's perception, they shift their cultivation to some marshy area to maximize water for their crops, as cited by an informant male participant; From the A tribe, an informant male participant cited; "My crops land at the lower Libi river border were washed away and adopted carpentry work while cultivating at the upper side of the river to compensate for the loss caused by flood" This is clear evidence that smallholders practice off-farm activities or possesses dry and wet land to compensate for the loss caused by climate variation or excessive perceived drought. Farmers cultivate crops in the swampy lowland area for the proximity of water for crops, and during the longer rainy period, they shift cultivation to the upland to avoid flood. Farmers think that drought occur more frequently today than 30 years back. This agrees with Qian and Zhu's ${ }^{32}$ on perception of climate variation and land use change. The drop in agricultural product due to climate change and variability has caused the farmers to involve in off-farm activities for income generating to compensate for the economic loss from the low harvest. The off-farm activity has it disadvantage in that many youth will move out of the villages to look for job and they don't know how long it will take. To cope with decreasing rainfalls, farmers juggle with mixing long cycle crops and short cycle crops on their farms of $\mathrm{A}$ and B. Smallholders mix both long and short season crops because of rain. Farmers consent that it rains sometimes and sometimes it doesn't. During long rain period, they harvest long seasonal crops and the short seasonal crops during the short rainy season. This research correspond to those made in southern Cameroon by Malla ${ }^{33}$ on perception of climate variability and pest-disease incident on crops and adaptive forest-agricultural practices that between 18 and 25 
crop species can be found in a single mixed food crop farm. A female participant in the focus group discussion of B said we plant many crops varieties so that we have a harvest during the small and long rainy season' Smallholder farmers consent that planting earlier will maximize the chances of crop growth with the already perceived drop in rainfall duration. They also consent of earlier harvest to prevent their crop especially maize from the attack of a weevil commonly known in Bulu as 'Mvande' (weevil) that mostly appear at the late period of the "small dry season". Application of chemical insecticides in both ethnic groups is still uncommon as the farmers complained of lack of finances to acquire the products, where to get them and how to apply. From questionnaire farmers of both groups adapt in climate variation by acquiring cultivable surfaces in both dry and swampy area to cope with drought.

\section{Conclusion}

The objective of this study is to evaluate the perception and knowledge of the small holder's farmer on climate change and variation and their adaptive and mitigation actions. This study has shown that most smallholder farmers of the two tribes of the area west of Dja reserve has perceived increased temperature, flood, and prolong drought, high rainfall variation and shift in timing of the season. Human activities and nature was highly perceived as the major causes of the climate change and variation thought the minority accused the local authority of failing to perform the traditional rites to their ancestors as the cause of the climate change and variation. Smallholders do perceive their microclimate variations and are able to adapt and mitigate. Their adaptation option include, diversification of their crop species, practicing off-farm activities, cropping earlier and harvesting earlier, possessing cultivated land in upland and lowland areas. They mitigate climate variation by deliberately conserving trees in their cocoa-base agro forest farm, thanks to sensitization groups made by some non-governmental organizations. The views of the farmers suggest that people's perceptions and their agricultural practices provide insights to what smallholders really need and prefer in adapting their agriculture to climatic variability. There is an urgent need for the integration of local knowledge in critical climate policies to improve agricultural practices. This may demand that adaptation interventions search for solutions together with farmers rather than prescribing solutions, which farmers may not view as attractive. Such analysis may give insights on the direction of local adaptations in future. Smallholders' knowledge points out what needs to be improved to enhance adaptive capacity, for example, access to organic fertilizers to ameliorate on their agricultural product, lack of technical knowhow on animal keeping. ${ }^{34,35}$

\section{Acknowledgements}

This work could not have come to completion without the help of number of persons and institutions. My special appreciations and gratitude goes to: Mbarga Pierre, researcher in the Specialized Research Center for Forest and Environment (CEREFEN) for his advice for work; Tegno Nguekam Erick Wilson, for realizing the map of the study area; the entire staff of CEREFEN for their hospitable concern for the work; Institute of Agricultural Research for Development (IRAD) for accepting me carries out the research work in the structure; the key field officials west of Dja reserve for their hospitality and providing relevant information.

\section{Conflict of interest}

There is no conflict of interest between the authors

\section{References}

1. Quiggin J, Adamson D, Chambers S, et al. Climate change, uncertainty and adaptation: The case of irrigated agriculture in the Murray-Darling Basin in Australia. Can J Agri Econ. 2010;58(4):531-554.

2. Kauti MK. Rural Livelihood Security Assessment for Smallholders Undergoing Economic changes and Agro-Climatic Events in Central Kenya. Research Institute for Humanity and Nature (RIHN): Kyoto, Japan; 2009.

3. ROK. National Policy for the Sustainable Development of Arid and Semi Arid Lands of Kenya. Special Programmes National, and Governement Printers: Nairobi, Kenya; 2007.

4. Below T, Artner A, Siebert R, et al. Micro-level: Practices to Adapt to Climate Change for African Small-Scale Farmers. IFPRI Discussion Paper 00953, International Food Policy Research Institute (IFPRI). USA; 2010 .

5. IAASTD. Executive Summary of the Synthesis Report of the International Assessment of Agricultural Knowledge, Science and Technology for Development (IAASTD). Johannesburg, South Africa; 2008.

6. McDowell JZ, Hess JJ. Accessing adaptation: Multiple stressors on livelihoods in the Bolivian highlands under a changing climate. Global Environ Change. 2012;22(2):342-352.

7. Hulme M, Doherty R, Ngara T, et al. African climate change: 19002100. Climate Res. 2001;17:145-168.

8. World Bank. Climate Change and Development. Washington, USA 2009 .

9. Lambrou Y, Nelson S. Farmers in a Changing Climate: Does Gender matter? FAO, Rome, Italy; 2010.

10. Mearn LO, Rosenzweig C, Goldberg R. Mean and variance change in climate scenario; Method, agricultural application and measures of uncertainty. climate change. 1997;35(4):367-396.

11. Boko M, Niang I, Nyong A, et al. Impacts, Adaptation and Vulnerability. Contribution of Working Group II to the Fourth Assessment Report of the Intergovernmental Panel on Climate Change. In: Parry ML, Canziani OF, editors. Cambridge University Press, Cambridge, UK; 2007. p. $433-467$.

12. Thompson J, Millstone E, Scoones I, et al. Agri-Food System Dynamics. Pathways to Sustainability in an Era of Uncertainty. STEPS Working Paper. 2007.

13. FAO. Climate Change and Food Security: A Framework Document Food and Agriculture Organization of the United Nations, Rome, Italy; 2008.

14. Newsham AJ, Thomas DSG. Knowing, farming and climate change adaptation in North-Central Namibia. Global Environ. Change. 2011;21(2):761-770.

15. Thomas DSG, Twyman C, Osbahr H, et al. Adaptation to climate change and variability: Farmer responses to intra-seasonal precipitation trends in South Africa. Climatic Change. 2007;83(3):301-322.

16. Tschakert P. Views from the vulnerable: Understanding climatic and other stressors in the Sahel. Global Environ Change. 2007;17(3-4):381-396.

17. Adger WN, Paavola J, Huq S, et al. Toward Justice in Adaptation to Climate Change. Fairness in Adaptation to Climate Change. MIT Press, Cambridge, USA; 2006. p. 1-19.

18. Mubaya CP, Njuki J, Mutsvangwa EP, et al. Climate variability and Change or multiple stressors? Farmer perceptions regarding threats to livelihoods in Zimbabweand Zambia. J Environ Manag. 2012;102:9-17.

19. Mertz O, Mbow C, Reenberg A, et al. Farmers' perceptions of climate change and agricultural adaptation strategies in rural Sahel. Environ Manag. 2009;43(5):804-816. 
20. Weber EU. What shapes on climate change? Wiley interdisciplinary reviews: climate change. 2010;1(3):332-342.

21. Smit B, Burton I, Klein RJT, et al. An anatomy of adaptation to climate change and variability. Climatic Change. 2000;45(1):223-251.

22. Sonké B and Couvreur T. Tree diversity of the Dja Faunal Reserve, southeastern Cameroon. Biodivers Data J. 2014;2:e1049.

23. Bernard R. Qualitative and Quantitative Approaches. In: Research Methods in Anthropology. 4th ed. AltaMira Press, Oxford, UK; 2006. p. $1-821$.

24. Lloyd-Evans S. Focus Groups. In: Desai V, Potter RB, editors. Doing Development Research. Sage Publication Ltd, London, UK; 2006.

25. Silverman D. Qualitative Research-Theory, Method and Practice. 2nd ed. Sage Publishers, London, UK; 2004.

26. Simon D. Your Questions Answered? Conducting Questionnaire Surveys. In: Desai V, Potter RB, editors. Doing Development Research. Sage Publication Ltd, London, UK; 2006.

27. Bryman A. Social Research Method. 3rd ed. Oxford University Press, New York; 2008.

28. Mayoux L. Quantitative, Qualitative or Participatory? Which Method, for What and When? In: Desai V, Potter RB, editors. Doing Development Research. Sage Publications Ltd, London, UK; 2006.
29. Nyanga P, Johnsen F, Aune J, et al. Smallholder Farmers' Perceptions of Climate Change and Conservation Agriculture: Evidence from Zambia. Journal of Sustainable Development. 2011;4(4):73-85.

30. Qin DH. Assessment on Environmental Changes in Western China. China Science Press, Beiging, China; 2002. p. 2967.

31. Mengistu KD. Farmers' perception and knowledge of climate change and their coping strategies to the related hazards: Case study from Adiha, central Tigray, Ethiopia. Agri Sci. 2011;2:138-145.

32. Qian W, Zhu Y. Climate Change in China from 1880 to 1998 and its Impact on the Environmental Condition. Springer link. 2001;50(4):419-444.

33. Malla A. Knowledge Systems and Adaptive Collaborative Management of Natural Resources in Southern Cameroon: Decision Analysis of Agro biodiversity of Forest Agriculture Innovation. Stellenbosch University, South Africa; 2009.

34. Newsham A, Thomas D. Agricultural Adaptation, Local Knowledge and Livelihoods Diversification in North-Central Namibia. Tyndall Centre for Climate Change Research, Norwich, UK; 2009.

35. Rao KPC, Ndegwa WG, Kizito K, et al. Climate variability and change: Farmer Silverman D. Qualitative Research-Theory, Method and Practice. 2nd ed. Sage Publishers, London, UK; 2004. 